\section{EREM 77/3}

Journal of Environmental Research, Engineering and Management Vol. 77 / No. 3 / 2021 pp. $50-65$

DOI 10.5755/j01.erem.77.3.29522
Palm Oil Industries in Malaysia and Possible Treatment Technologies for Palm Oil Mill Effluent: A Review
Accepted after revision 2021/08

\title{
Palm Oil Industries in Malaysia and Possible Treatment Technologies for Palm Oil Mill Effluent: A Review
}

\section{Risky Ayu Kristanti*}

Indonesian Institute of Sciences, Pasir Putih I, 14430 Jakarta, Indonesia

\section{Tony Hadibarata}

Environmental Engineering Program, Faculty of Engineering and Science, Curtin University Malaysia,

CDT 250, Miri, Malaysia

\section{Adhi Yuniarto}

Department of Environmental Engineering, Faculty of Civil, Planning, and Geo-Engineering, Institut Teknologi Sepuluh Nopember, Surabaya 60111, Indonesia

\section{Abrar Muslim}

Chemical Engineering Department, Engineering Faculty, Universitas Syiah Kuala, Banda Aceh, 23111, Indonesia

\footnotetext{
*Corresponding author: risky.ayu.kristanti@lipi.go.id
}

Palm oil industries have become the main sector to boost the economic revenue in tropical countries, especially in South East Asia. In the recent years, the global production of palm oil reached 72 million metric tons in 2018, increasing from about 68 million metric tons in 2017. During that period, Malaysia is currently the second world producer of palm oil after neighbouring country Indonesia. Both countries are the leading exporters of palm oil with $84 \%$ of worldwide production.

A detailed analysis of the palm oil business in Malaysia, the environmental issues that have arisen, and the treatment technology used to effectively treat palm oil mill wastewater are reviewed to gain an understanding of environmental 
sustainability. In Malaysia, most of the oil palm plantations are owned by private conglomerates ( $61 \%$ ), followed by the independent smallholders (16\%), the Federal Land Development Authority (13\%), state agencies (6\%), the Federal Land Consolidation and Rehabilitation Authority (3\%), and Rubber Industry Smallholders Development Authority (1 $\%)$. However, the rate of deforestation has increased due to the expansion of oil palm plantations in Malaysia. Palm oil mill effluent is also considered as one of the major environmental issues since it reduces the water quality index. Some techniques are implemented to treat palm oil mill effluent, such as anaerobic ponding systems, integrated anaerobic-aerobic bioreactors, coagulation and flocculation, thermochemical treatment, vermicomposting, membrane filtration, photocatalysis, moving bed biofilm reactors, and zero liquid discharge. Zero liquid discharge method is considered an appropriate method since this method provides a better waste recovery.

Keywords: palm oil tree, mill effluent treatment technology, Malaysia palm oil industry.

\section{Introduction}

The oil palm tree originated in Africa and was first planted about 100 years ago (Awalludin et al., 2015). The palm oil industries have become the main sector to boost the economic revenue in tropical countries, especially in South East Asia. In the recent years, the global production of palm oil reached 72 million metric tons in 2018 , increasing from about 68 million metric tons in 2017 (Table 1). During that period, Indonesia and Malaysia were the leading exporters of palm oil worldwide with $84 \%$ of worldwide production. Total Malaysian exports of oil palm products increased by $12.1 \%$ from 24.88 million tons in 2018 to 27.88 million tons in 2019. However, the total export revenue was reported to have decreased by $4.0 \%$ to RM64.84 billion because of price reduction in world trade (MPOB, 2019). Malaysia has faced a challenge in the oil palm industry due to decreasing production, export, and price compared with the previous year.
Another problem is the decreasing demand from the EU because of several issues. Recently, Malaysia has faced serious problems related to the prohibition of importing CPO commodities by the EU. Environmental concerns, such as deforestation of rain forests, are a compelling reason for the ban, although a closer look concludes that European domestic interests are also the main incentive. The main objective of the proposed palm oil import ban is to reduce or stop deforestation of oil palm plantations in Indonesia and Malaysia. As shown in Table 2 , the ban would certainly destroy the Malaysian industry since the $E U$ is the top importer countries for palm oil (MPOB, 2018). The EU has stated that their decision is based on rain forest deforestation in Malaysia which has led to biodiversity loss. Malaysia makes the palm oil industries as one of the major country incomes as well as the major suppliers of palm oils in the world since oil

Table 1. World production and consumption of palm oil (in million MT) (MPOB, 2019)

\begin{tabular}{l|c|c|c|c}
\hline \multirow{2}{*}{ Country } & \multicolumn{3}{|c}{ Production } & \multicolumn{2}{c}{ Consumption } \\
\cline { 2 - 5 } & 2018 & 2017 & 2018 & 9.22 \\
\hline Indonesia & 41.00 & 37.10 & 11.80 & 0.56 \\
\hline Malaysia & 19.52 & 19.92 & 0.58 & 9.30 \\
\hline Rest of the world & 11.52 & 11.23 & 9.07 & 7.56 \\
\hline India & - & - & 7.58 & 5.10 \\
\hline EU & - & - & 5.40 & 1.33 \\
\hline China & - & - & 1.45 & \\
\hline USA & & & \\
\hline
\end{tabular}


Table 2. Export of biodiesel from Malaysia (MPOB, 2018)

\begin{tabular}{l|c|c|c|c}
\hline \multirow{2}{*}{ Country } & \multicolumn{2}{|c|}{ 2016 } & & 2017 \\
\cline { 2 - 4 } & Ton & Million liters & Ton & Million liters \\
\hline European Union & 67,766 & 79.00 & 212.273 & 241.00 \\
\hline Switzerland & NA & NA & 11,945 & 13.00 \\
\hline Peru & NA & NA & 5,978 & NA \\
\hline Albania & 10,002 & 11.00 & 3,774 & NA \\
\hline China & 2,586 & 3.00 & NA & NA \\
\hline South Korea & 604 & 0.60 & 1,049 & 1.00 \\
\hline Japan & 426 & 0.48 & NA & NA \\
\hline Singapore & 96 & 0.10 & 61 & 0.2 \\
\hline USA & 80 & 0.09 & 197 & 0.07 \\
\hline India & 21 & 0.02 & 14 & 0.01 \\
\hline Vietnam & NA & NA & 235,291 & 267.00 \\
\hline Total & 83,581 & 94.29 & & \\
\hline
\end{tabular}

${ }^{*} N A=$ Not available

palm plantations grow well in the tropical climate (Wu et al., 2010). The crude palm oil is mixed with crude diesel to produce biodiesel, a clean and biodegradable biofuel (Zhang et al., 2020). This information shows that palm oil production could improve the country's economy due to the large usage area. However, the industry might impact the environment if palm oil mill effluents are not treated before discharging into the environment (Borja and Banks, 1994,). It is necessary to treat the effluent before discharging into the environment to ensure the sustainability of palm oil production.

\section{Malaysia Oil Palm Industry Situation}

The feedstock used in biodiesel production in 2018 is shown in Fig. 1. The composition of feedstock used is $35 \%$ of palm oil, $26 \%$ of soybean oil, $16 \%$ of rapeseed oil, $11 \%$ of used cooking oil, $7 \%$ of animal fat, and $6 \%$ of other fats. Oil palm yield is the most effective feedstock production in the world, and is about 10 times higher than that of soybean, 6.9 times higher than that of sunflower, and 6.3 times higher than that of rapeseed. Fresh fruit bunches are harvested approximately 24 to 30 months after planting, and production continues until the tree
Fig. 1. Feedstock used in biodiesel production (2018) (von Schenck, 2020)

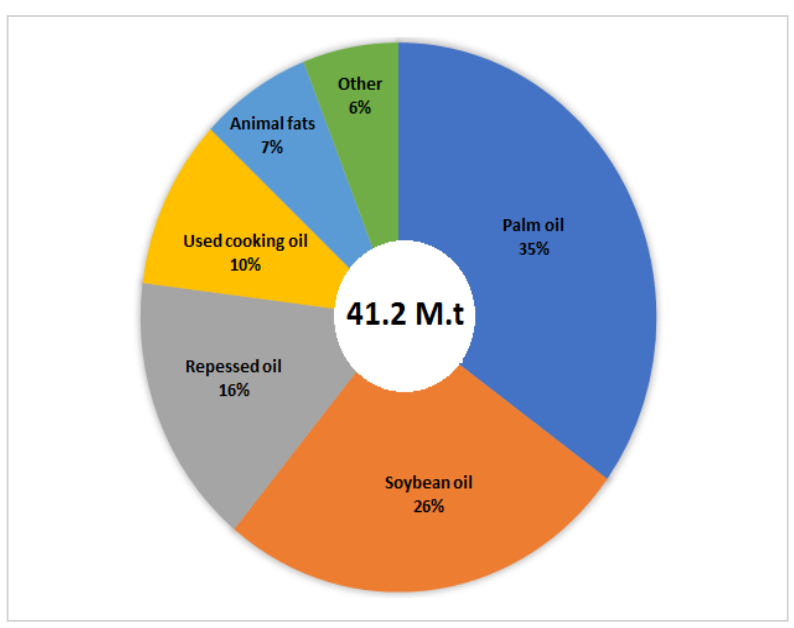

reaches the maximum age of 30 years. The oil palm tree produces 9 to 15 fresh fruit bunches per year and 10 to 25 kg per bunches (MPOB, 2019).

In Malaysia, most of the oil palm plantations are owned by private estates conglomeration (61\%), such as Sime Darby, IOI Group, and Kuala Lumpur Kepong (Fig. 2). Other owners of the plantations are independent smallholders (16\%), FELDA (13\%), states agency (6\%), FELCRA (3\%), and RISDA (1 \%) (MPOB, 2016). Currently, the 
Fig. 2. Distribution of oil palm planting area by category of stakeholders (MPOB, 2016)

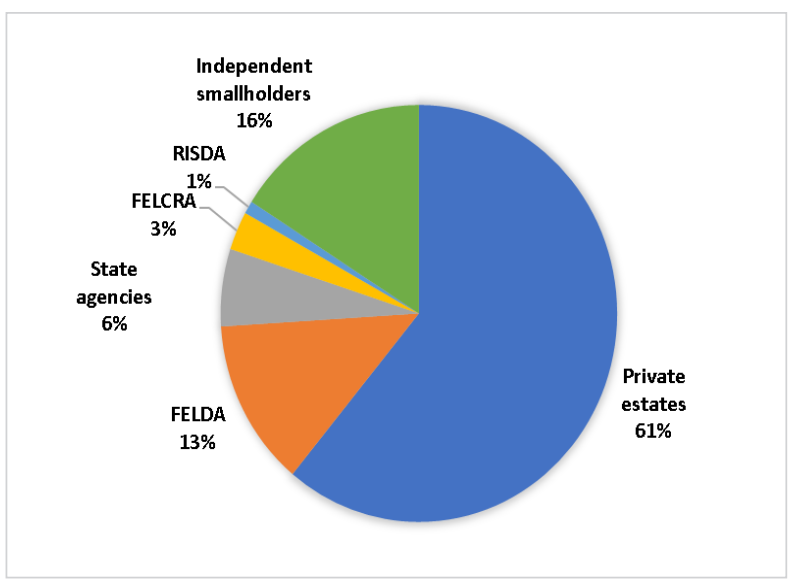

Fig. 3. Biomass availability in Malaysia in 2013 (million tonnes) (MPOB, 2016)

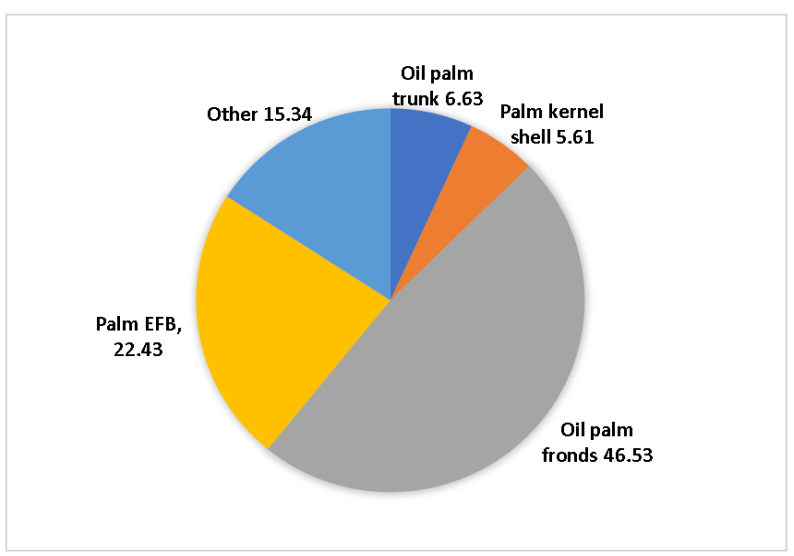

palm oil industry is the major export-oriented industry and is one of the main contributors to Malaysia's national revenue because of its huge contribution to the economic development of Malaysia. Thus, this industry is categorized as one of National Key Economic Area (NKEA) in Malaysia (Wu et al., 2010). Due to its abundant resource and supply, the palm oil industry is also the main biomass source in Malaysia. The industry has produced huge amounts of biomass nationwide, much larger than other biomass sources such as organic waste from oil palm, timber, rice husk, livestock, and municipal solid waste (Fig. 3). Biomass from oil palm contains energy that can be processed into electricity, fuel, heat, and other forms of energy. Biomass composition in Malaysia is divided into three categories: oil palm, agricultural/forestry, and municipal waste, while the oil palm biomass sector contributes more than $80 \%$ of Malaysia's available biomass (MPOB, 2016). The area of the oil palm plantation in 2019 was 5.9 million hectares, an increase of $0.9 \%$ as against 5.85 million hectares in the previous year. East Malaysia occupies the largest plantation area in the country, with 3.13 million hectares or $53.1 \%$ of the total Malaysian oil palm planted area, while oil palm planted in Peninsular Malaysia amounts to 2.77 million hectares or $46.9 \%$ (Table 3). CPO production in 2019 increased to 19.86 million tons, an increase of $1.8 \%$ as against 19.52 million tons recorded in 2018. This result corresponded to the productivity of fresh fruit bunch (FFB) which increased to 17.19 tons /hectare, up by $0.2 \%$ from the previous year (MPOB, 2017).

As one of the largest palm oil producers in the world, Malaysia introduced the National Biofuels Policy in 2006, which established a palm biodiesel mandate. Malaysia has the highest palm oil yield per hectare in the world, which is significantly higher than soybean and rapeseed. Therefore, palm oil has become the main feedstock of biodiesel in the country. However, studies claim that there are some factors which would impede biodiesel

Table 3. Summary of Malaysian palm oil industry in 2018-2019 (MPOB, 2019)

\begin{tabular}{l|c|c|c|c|c|c|c}
\hline \multirow{2}{*}{ Area } & \multicolumn{2}{|c|}{ Planted area (Hectare) } & \multicolumn{2}{c|}{ CPO production (Tonnes) } & \multicolumn{2}{c}{ FFB Yield (Tonnes/Hectare) } \\
\cline { 2 - 8 } & 2018 & 2019 & 2018 & 2019 & 2018 & 2019 \\
\hline Peninsular & $2,727,608$ & $2,769,003$ & $10,197,446$ & $10,583,788$ & 17.44 & 17.95 \\
\hline Malaysia & $1,572,477$ & $1,586,673$ & $4,179,339$ & $4,237,411$ & 15.74 & 15.56 \\
\hline $\begin{array}{l}\text { Sarawak } \\
\text { Sabah }\end{array}$ & $1,549,245$ & $1,544,481$ & $5,139,356$ & $5,037,168$ & 18.16 & 17.66 \\
\hline Malaysia & $5,849,330$ & $5,900,157$ & $19,516,141$ & $19,858,367$ & 17.16 & 17.19 \\
\hline
\end{tabular}


development in the country by using palm oil as the feedstock of biodiesel, such as high feedstock prices, competition with food, engine compatibility, the sustainability of production, fuel subsidies, and crude oil prices (Johari et al., 2015). So, alternative feedstock with lower cost and higher productivity is also being considered in Malaysia. Microalgae is proven to be a suitable raw material for biodiesel due to its high productivity to produce significant quantities of biomass and bio-oil fit for transformation to biodiesel and also low energy and production cost (Jayakumar et al., 2017). According to the United States Department of Agricultural, Malaysia produced 1245 million liters of biodiesel in 2018 while the consumption of petrodiesel was 11,624 million liters. Malaysia promoted B20 for the transportation sector in certain areas of the country in 2020 (Shah, 2020; Wahab, 2019).

\section{Environmental Impact}

\section{Deforestation}

Malaysia is the second-largest palm oil producer in the world after Indonesia. Malaysia has committed to protecting the tropical forest, which accounts for more than half of the country's total forest land. However, along with the increase of global demand for palm oil, the rate of conversion of tropical forests to oil palm plantations is also increasing. Malaysia had the world's highest rate of forest loss between 2000 and 2012. Forest destruction in Malaysia during this period accounted for $14.4 \%$ (47,278 square kilometers) of total forest cover, an area larger than Denmark. About $10 \%$ of greenhouse gas emissions come from deforestation in the tropical forest making it a significant contributor to climate change. Palm oil-based biofuels actually have three times the climate impact of regular fossil fuels due to their $\mathrm{CO}_{2}$ and methane emissions (Omran and Schwarz-Herion, 2020; Vijay et al., 2016). Another negative impact is the loss of biodiversity, such as the extinction of medicinal plants and loss of habitat for endangered animals. The destruction of natural habitats deprives animals of the basis for their existence, causing an irreversible loss of biological diversity. As their forest habitat is cleared, endangered species, such as the orangutan, Borneo elephant, and Sumatran tiger, are being pushed closer to extinction. Local communities that depend on the forest are also threatened. Conflicts between humans and animals often occur due to the increasingly pressing habitat of animals (Syahza, 2019).

\section{Waste generation from palm oil mills}

Waste products generated during oil palm processing consist of liquid waste (POME) and solid waste such as oil palm trunk (OPT), oil palm fronds (OPF), empty fruit bunches (EFB), palm juice fiber (PPF), and palm shells. POME is the wastewater produced during oil palm production and consists of various suspended materials, and it is characterized as non-toxic wastewater since there is no addition of chemical during the oil extraction process. However, as per other wastewaters, POME poses environmental problems due to large oxygen depleting capability in the aquatic environment and the concentration of organic and nutrient contents. Previous studies have shown that POME consists of 95-96\% of water, $04-5 \%$ of total solids, $2-4 \%$ of suspended solids, $0.6-0.7 \%$ of palm oil, and a certain range of inhibitors and toxicants. Furthermore, the composition of nutrients in POME $(\mathrm{mg} / \mathrm{L})$ are 2726 of chemical oxygen demand (COD), 1270 of total organic carbon (TOC), 316.7 of total nitrogen (TN) and 257.6 of phosphate (Hariz et al., 2019; Irvan, 2018). Since POME has high nutrient concentrations and pollutants when being released into a body of water, it will cause algal blooms and subsequent loss of biologically active oxygen in the water, and consequently, all life in aquatic ecosystems would be destroyed (Donald, 2004). Among the solid waste generated during oil palm production, more than $50 \%$ is contributed by OPF. OPF usually decomposes naturally in the soil to become soil fertilization, erosion control, and long-term benefits from nutrient recycling. OPT is usually allowed to burn or rot in plantation areas. However, freshly felled stalks, with their high moisture content, cannot be easily burned on site. Leaving the stems in the field without further processing physically hinders the process of planting a new plant, as the stems take about five years to fully rot. OPT is converted into sawwood, fiberboard, plywood, or wood for furniture purposes (Abdullah et al., 2012).

\section{Air quality impact}

Burning is a cheap technique that is commonly used for land clearing in natural forests and plantations including oil palm. The forest burning releases massive smoke 
and carbon dioxide into the atmosphere, leading to severe decreases in air quality and contributing to climate change. Furthermore, fires in peat areas are very difficult to extinguish, and highly unpredictable and uncontrollable. The incineration of palm biomass is also the main source of air pollution. Empty fruit bunches, shells, and fibers are burnt to provide power generation for the mills. However, incinerators release various types of pollutants such as polycyclic aromatic hydrocarbons, volatile organic compounds, incomplete hydrocarbons, nitrogen, and particulate matter, which leads to health deterioration and environmental degradation. This process of waste incineration poses a significant threat to public health and the environment (Izah et al., 2016). Air pollution has various health effects. Short-term exposure to air pollutants is closely related to chronic obstructive pulmonary disease (COPD), cough, shortness of breath, wheezing, asthma, while long-term health effects from air pollution include heart disease, lung cancer, and respiratory diseases such as emphysema (Eze et al., 2014; Kelishadi and Poursafa, 2010).

\section{Waste Management}

\section{Control of air emissions}

The palm oil industry must monitor their air emission regularly and the inspection by authorized body must be conducted quarterly to ensure the air emission does not exceed the national limit. The industry should follow the Regulation Act of 1978 about the implementation of environmental quality that arranges the guideline for the quality assurance and air quality monitoring. According to the Regulation Act, the standard of particulate matter (PM) in gas emission must not exceed $0.5 \mathrm{~g} / \mathrm{m}^{3}$. PM emitted from incinerators and boilers should be 20 to 100 microns for soot and tar droplets, and 3000 to $4000 \mathrm{mg} / \mathrm{m}^{3}$ for dust loads. Separation of solid waste before the incineration process is conducted to prevent incomplete combustion and produce black smoke (Abdullah et al., 2015; Sumathi et al., 2008).

\section{Conventional oxidation ponds}

Liquid waste is generated from an extraction of palm oil through a wet process named decanter. Oxidation pond is a biological treatment that is commonly used to treat liquid waste from palm oil industry. Oxidation ponds or stabilization ponds are large and shallow maintaining the interaction of aquatic organisms such as algae and bacteria with sunlight. Liquid effluent is consumed by algae and bacteria as food while algae can use sunlight as energy to do photosynthesis. The oxygen released during photosynthesis is used by bacteria to grow. Sludge deposit in the pond must eventually be removed by dredging. This treatment ensures that during the aerobic and anaerobic system, the biological oxygen demand (BOD) level is lower than 25,000 mg/L (Ahmad et al., 2005b). The addition of charcoal or a sand bed into the oxidation pond to filter liquid effluent might be an alternative method to speed up the cleaning process. This approach increases the removal of the particulate matter in the liquid effluent before processing to lagoon treatment. In the lagoon system, several ponds working in parallel in which the inlet flow and the outlet flow are equal form lagoon plants. Furthermore, the addition of aquatic plants is an alternative and resourceful clean up technique for phytoremediation of wastewater. Aquatic plants act as a natural absorber for organic pollutant and inorganic pollutant. Some free-floating aquatic plants are well-known for their ability to absorb the pollutant from the aquatic environment such as water hyacinth, water ferns, water lettuce, and duckweed. Active transport of pollutants in the aquatic plant occurs from the roots, then is transferred to other plant bodies such as stem and leaves (Gunathilake et al., 2018; Iha and Bianchini, 2015; da Silva et al., 2017; Daud et al., 2018; Abbas et al., 2019).

\section{Solid wastes converted into fertilizer and livestock feed}

Solid waste generated by palm oil could provide an alternative, low cost, and useful material for livestock feed. Livestock feed with high nutritional content helps determine the productivity of the animal. However, livestock industries need to produce a cheaper and readily available protein ingredient of animal feed due to increased competition of human food. Palm kernel cake (PKC) is a solid waste of oil palm that is commonly used by livestock industries. PKC contains $16 \%$ of crude protein and all the nine essential amino acids for monogastric animals. The composition of essential amino acids is higher than that of rice bran. PKC is also relatively high in the content of minerals, which are calcium, phosphorus, magnesium, zinc, sodium, potassium, copper, manganese, and iron. 
On the other hand, the empty fruit bunch is used as fertilizer, in terms of providing sufficient mineral requirements, because of its non-toxic nature and fertilizing properties, such as nitrogen, phosphorus, and potassium as well as micronutrients such as iron, zinc, copper, and manganese. EFB is converted into eco-friendly and sustainable organic manure by co-composting with other solid waste to increase soil fertility (Abdullah and Sulaiman, 2013; Ngieng, et al., 2021; Kristanti, et al., 2021).

\section{Current Status of Palm Oil Effluent Treatment}

The development in palm oil industries has caused environmental pollution due to the increment of palm oil mill effluent, which is generated during the extraction of palm oil. Due to the high organic content of the effluent, the effluent must be treated before discharging into the environment to prevent pollution (Hashiguchi et al., 2020). A previous study has shown that the effluent is a hot brownish sticky liquid with temperature ranging from 353K to 363K (Tabassum et al., 2015). The treatment of POME should be conducted due to its high biochemical oxygen demand and high chemical oxygen demand (Lee et al., 2019). The presence of complex organic acids causes the very low pH of POME (pH 4.5) (Lee et al., 2019; Tabassum et al., 2015). Every country has a different department that is responsible to control the quality of POME, for example, Malaysia has the Department of Environment to ensure POME meets the regulation with the BOD level at $100 \mathrm{mg} / \mathrm{L}$ (Hashiguchi et al., 2020). Currently, various techniques such as mechanical, chemical or biological methods have been developed for the treatment of POME (Tan and Lim, 2019). The most common POME treatment technology is anaerobic digestion by microorganisms. With high nutrient content, POME is a suitable media for microorganisms to thrive. Microorganisms can consume and break down POME, turning them into harmless by-products (Kamyab et al., 2018). Other advanced treatment methods for POME that are also investigated, such as coagulation and flocculation treatment, thermochemical treatment, membrane filtration, vermicomposting, photocatalytic, and moving-bed biofilm reactors, as summarized in Table 4.

\section{Anaerobic ponding treatment}

The ponding system is the most conventional technology for the treatment of the effluent containing a high concentration of organic carbon such as POME (Tan and
Lim, 2019). It involves various species of anaerobic microbes that degrade organic pollutants. The process of pollutant decomposition by anaerobic microbes is performed without the presence of oxygen, followed by hydrolysis, acidogenesis, and methanogenesis to convert the intermediate compounds into methane gas and carbon dioxide. This approach has great potential for the integration of pollutant decomposition and biogas production to generate electricity (Yap et al., 2020; Monir et al., 2018). This method also provides greater advantages over other alternative treatments because it does not require energy for aeration. However, the aerobic ponding system has limitations such as long retention time and long start-up period (Khadaroo et al., 2019).

The anaerobic ponding system has the advantage of lower cost and energy consumption. This is because anaerobic ponding treatment does not require any oxygen supplied to the pond, which can save the money of palm oil mill owners (Khadaroo et al., 2019). The anaerobic ponding system does not pollute the environment as it involves the natural decomposition of organic compounds in the pond. Besides, the product from anaerobic treatment, which is methane gas, could be recovered for energy generation in the oil palm mill (Abdurahman et al., 2013). The sludge generated from the anaerobic treatment is used to produce fertilizers (Chin et al., 2020). However, the disadvantage of anaerobic ponding treatment is the requirement of large areas for the ponding systems ( $A b$ durahman et al., 2013). This reduces the space available for palm oil mill expansion. The anaerobic digestion process needs to be managed frequently due to instability of the process and the hydrolysis process involved in anaerobic treatment limits the rate of decomposition (Khadaroo et al., 2019). If the biogas generated is not recovered for energy production, the methane in the biogas worsens global warming since methane is a greenhouse gas (Abdurahman et al., 2017). Anaerobic ponding treatment has the disadvantage of high cost in removing the sludge sedimented at the bottom of the pond (Harsono et al., 2014). Long hydraulic retention time is required in the decomposition of organic compounds to achieve higher efficiency of effluent treatment ( $\mathrm{Ng}$ et al., 2019b).

\section{IAAB}

$I A A B$ is a high-rate bioreactor that combines aerobic and anaerobic processes and is capable of treating POME within a short period of time. Both processes involve 
the microorganisms that use dissolved oxygen in the conversion of organic wastes to biomass and carbon dioxide, and complex organic wastes are degraded into methane gas, carbon dioxide, and water in the absence of oxygen. The aerobic process is widely implemented in the treatment of organic wastewaters for achieving a high degree of treatment efficiency, while in the anaerobic process, wastewater is treated based on resource recovery and pollution control (Chan et al., 2012; Ohimain and Chibuezelzah, 2017; Hadibarata et al., 2017). The anaerobic compartment is designed to have a high solid retention time with a low hydraulic retention time. In the aerobic compartment, higher removal of soluble organic matter is achieved, and followed by flocculation of produced biomass, resulting in a lower concentration of suspended soil effluent (Chan et al., 2012; Chan et al., 2009).
IAAB has the advantage of removing a large number of organic compounds at high efficiency. IAAB can reduce the chemical oxygen demand, biochemical oxygen demand, and total suspended solids by up to $99 \%$. With every gram of chemical oxygen demand removed, 0.24 $L$ of methane is produced and recovered for electricity generation (Chan et al., 2012). IAAB has the disadvantage of energy required to return the activated sludge back to the aerobic compartment (Chan et al., 2012). Due to the bioreactor's limited volume, only a limited volume of effluent can be treated.

\section{Coagulation and flocculation treatment}

Coagulation-flocculation is regarded as a popular physicochemical treatment for POME due to simplicity in operation and design, low energy consumption, and high

Table 4. Possible treatment methods for palm oil mill effluent

\begin{tabular}{|c|c|c|c|}
\hline Treatment & Advantage & Disadvantage & References \\
\hline $\begin{array}{l}\text { Anaerobic ponding t } \\
\text { reatment }\end{array}$ & $\begin{array}{l}\text { Lower cost and energy } \\
\text { consumption; } \\
\text { Safer by product; } \\
\text { Production of methane gas; } \\
\text { Fertilizers from sludge }\end{array}$ & $\begin{array}{l}\text { Large area for the ponding } \\
\text { system; } \\
\text { Instability of the process; } \\
\text { Long hydraulic retention time }\end{array}$ & $\begin{array}{l}\text { (Abdurahman et al., } \\
\text { 2013; Chin et al., 2020; } \\
\text { Khadaroo et al., 2019) } \\
\text { (Ng et al., 2019b) }\end{array}$ \\
\hline $\begin{array}{l}\text { Integrated } \\
\text { anaerobic-aerobic } \\
\text { bioreactor (IAAB) }\end{array}$ & $\begin{array}{l}\text { Removing large number of } \\
\text { pollutants; } \\
\text { High efficiency; } \\
\text { Methane gas is recovered }\end{array}$ & High energy required & (Chan et al., 2012) \\
\hline $\begin{array}{l}\text { Coagulation and } \\
\text { flocculation }\end{array}$ & $\begin{array}{l}\text { Low maintenance cost; } \\
\text { Simple operation; } \\
\text { Fertilisers from sludge }\end{array}$ & $\begin{array}{l}\text { Must be combined with other } \\
\text { treatment; } \\
\text { Some of by-products are toxic }\end{array}$ & $\begin{array}{l}\text { (Nasrullah et al., 2020) } \\
\text { (Lek et al., 2018) (Lee } \\
\text { et al., 2019) (Huzir et } \\
\text { al., 2019) }\end{array}$ \\
\hline Thermochemical & $\begin{array}{l}\text { Low initial construction cost; } \\
\text { Low operational cost; } \\
\text { Hydrogen gas generation }\end{array}$ & $\begin{array}{l}\text { Failure of water gas shift } \\
\text { reaction can release carbon } \\
\text { monoxide }\end{array}$ & (Cheng et al., 2019) \\
\hline $\begin{array}{l}\text { Vermicomposting } \\
\text { technology }\end{array}$ & $\begin{array}{l}\text { Generating fertilisers as final } \\
\text { products; } \\
\text { Low operational cost; } \\
\text { No air pollution }\end{array}$ & $\begin{array}{l}\text { Slow process; } \\
\text { Requires large space; } \\
\text { Requires greater care }\end{array}$ & $\begin{array}{l}\text { (Lim and Wu, 2015; } \\
\text { Singh et al., 2011) }\end{array}$ \\
\hline Membrane filtration & $\begin{array}{l}\text { High efficiency; } \\
\text { Low energy requirement; } \\
\text { Biogas generation; } \\
\text { Prevent eutrophication; } \\
\text { Processes are relatively } \\
\text { simple for scale up }\end{array}$ & $\begin{array}{l}\text { Equipment cost was high; } \\
\text { High flow rate can damage } \\
\text { shear sensitive materials }\end{array}$ & $\begin{array}{l}\text { (Abdurahman et al., } \\
\text { 2017) (Aziz et al., } \\
\text { 2020) (Lee et al., 2019) }\end{array}$ \\
\hline
\end{tabular}


Continued

\begin{tabular}{|c|c|c|c|}
\hline Treatment & Advantage & Disadvantage & References \\
\hline Photocatalysis & $\begin{array}{l}\text { Low cost; } \\
\text { Reusable; } \\
\text { Eco-friendly } \\
\text { Complete degradation; } \\
\text { Effective for inorganic pollutant }\end{array}$ & $\begin{array}{l}\text { Releasing of titanium dioxide } \\
\text { to the environment }\end{array}$ & $\begin{array}{l}\text { (Ng et al., 2019b) } \\
\text { (Alhaji et al., 2016) } \\
\text { (Lee et al., 2019) }\end{array}$ \\
\hline $\begin{array}{l}\text { Moving-bed biofilm reactor } \\
\text { (MBBR) }\end{array}$ & $\begin{array}{l}\text { Less space required for reactor } \\
\text { set up; } \\
\text { Backwashing is not required; } \\
\text { Fertilizers are generated; } \\
\text { Easy to use for inexperienced } \\
\text { plant operators; } \\
\text { Low hydraulic retention time }\end{array}$ & $\begin{array}{l}\text { High construction cost; } \\
\text { Manual monitoring }\end{array}$ & $\begin{array}{l}\text { (Bakar et al., 2018) } \\
\text { (Leyva-Díaz et al., } \\
\text { 2020) }\end{array}$ \\
\hline Zero-discharge & $\begin{array}{l}\text { Fertilizers are generated; } \\
\text { Biogas generation; } \\
\text { Lower waste volume; } \\
\text { Recycle water in site }\end{array}$ & High capital cost & $\begin{array}{l}\text { (Tabassum et al., } \\
\text { 2015) (Lee et al., 2019) }\end{array}$ \\
\hline Phytoremediation & $\begin{array}{l}\text { Potential to be converted into } \\
\text { organic fertilizer; } \\
\text { An increase in biomass and } \\
\text { superior in biochemical content; } \\
\text { Provides more nutritious food } \\
\text { for aquaculture fish. }\end{array}$ & $\begin{array}{l}\text { Slow process than other } \\
\text { treatment; } \\
\text { Seasonally dependent }\end{array}$ & $\begin{array}{l}\text { (Kadir et al., 2020; Ng } \\
\text { and Chan, 2017) }\end{array}$ \\
\hline Adsorption & $\begin{array}{l}\text { Simple operation; } \\
\text { Ecological purity; } \\
\text { More safety; } \\
\text { Less operating costs }\end{array}$ & $\begin{array}{l}\text { Adsorbent recovery possibly } \\
\text { requiring a special, expensive } \\
\text { distillation; } \\
\text { Spent adsorbent may be } \\
\text { considered a hazardous waste }\end{array}$ & $\begin{array}{c}\text { (Ahmad et al., 2005a; } \\
\text { Sia et al., 2017; Hii et } \\
\text { al., 2021, Lai et al., } \\
\text { 2021) }\end{array}$ \\
\hline Microbial degradation & $\begin{array}{l}\text { Generation of methane gas } \\
\text { Lower cost } \\
\text { Permanently eliminate waste } \\
\text { Environmentally friendly }\end{array}$ & $\begin{array}{l}\text { Duration of treatment } \\
\text { Nutrient availability } \\
\text { Different capability of each } \\
\text { microorganism species }\end{array}$ & $\begin{array}{l}\text { (Mohd-Nor et al., } \\
\text { 2019; Okwute et al., } \\
\text { 2015) }\end{array}$ \\
\hline
\end{tabular}

performance in filtering suspended solid. A previous study showed that effective decolorization of POME is achieved by using chemical coagulants. However, some researches have been conducted to find alternative natural coagulants and flocculants to replace alum and other chemical coagulants. Rice-husk-ash and chickpea (Cicer arietinum) are the natural coagulants-flocculants that have the potential to replace the chemical coagulants and flocculants for POME treatment. The combination of rice-husk-ash in a matrix of cement and filtration bed can trap up to $95 \%$ of turbidity and bacteria present in the water (Huzir et al., 2019; Lek et al., 2018).
Another innovation includes the combination of coagulation to destabilize, emulsify, or dissolve contaminants in an aqueous medium by introducing an electrical current into the medium. This process basically involves the dissolution of metal cations from the anode with the simultaneous formation of hydroxyl ions. This method is used as a complement to other treatments in the polishing step such as biological treatment and the advanced oxidation process (Nasrullah et al., 2020). The advantages of coagulation and flocculation using electrocoagulation are low maintenance cost and low difficulty in operation (Nasrullah et al., 2020). The sludge 
produced is used as a fertilizer to increase soil fertility, which can increase the yield of oil palm fruits (Lek et al., 2018). Coagulation and flocculation treatment can remove most of the suspended solids in the effluent and some chemical oxygen demand. The disadvantage of coagulation and flocculation is that this treatment cannot be applied without the help of other treatments. This treatment method should be applied together with membrane filtration or anaerobic digestion to get the best result of treatment (Lee et al., 2019). The application of chemical coagulants such as alum pollutes the environment as the chemical sludge produced after the coagulation is toxic (Huzir et al., 2019).

\section{Thermochemical treatment}

Thermochemical treatment involves the supercritical water gasification of the effluent in the presence of catalysts at high temperatures. POME is transformed into useful products such as syngas. Carbon monoxide is produced at the end of the steam reforming process. A water-gas shift reaction is carried out to convert the carbon monoxide into carbon dioxide and hydrogen gas. The syngas produced mainly consists of hydrogen gas, which is recovered for other purposes such as for laboratory instrument. A previous study has reported that the thermochemical process could remove over $90 \%$ of BOD and COD. The treatment also has the ability to remove the odour and colour of the effluent (Lee et al., 2019; Ng et al., 2019a).

Thermochemical treatment is the most common technology for converting biomass into a higher heating value fuel. The main conversion processes comprise direct combustion to provide heat, liquid fuel, and process to generate electricity. POME is a feedstock that is more favourable than coal for gasification because it has low concentration of sulphur and a less reactive character. The product of gasification is referred to as producer gas, which is an energy-rich mixture of flammable gases such as hydrogen, methane, and other impurities such as carbon dioxide, nitrogen, and sulphur. Another advantage of the thermochemical treatment is low initial construction cost and operational cost. However, the release of carbon monoxide into the environment during the thermochemical process is a limitation of this technology (Cheng et al., 2019).

\section{Vermicomposting technology}

Vermicomposting is the utilization of microorganisms in the composting process to enhance the decomposition of organic waste and produce a better end product. It may be considered an interesting eco-innovation approach in biowaste treatment due to the circular economy concept, transferring different types of organic wastes into renewable energy sources. Vermicompost is claimed to be the potential fertilizer replacing the chemical synthesis, thus supporting the sustainability of the palm oil industry (Rupani et al., 2010). Microorganisms break down organic compounds aerobically while earthworms improve the aeration in the sludge by increasing its porosity. The addition of earthworms has proven to increase the rate of organic compounds decomposition. Earthworms reduce the carbon to nitrogen ratio in the composting process, which improves the mineralization and increases soil nutrients (Lim and Wu, 2015). The existence of earthworms results in waste stabilization, sanitation of organic waste, pathogen reduction, and elimination of toxic compounds (Singh et al., 2011).

Vermicomposting is the decomposition of organic residues into a valuable finished product by non-thermophilic processes using earthworm and mesophilic microbes. Earthworms convert industrial waste into a high-quality fertilizer as a final product by decreasing waste toxicity, decrease the organic carbon content, improve the $\mathrm{C}: \mathrm{N}$ ratio, change the composition of waste, and retain macro and micronutrients (Lim and Wu, 2015). On the other hand, the fertilizer produced by this treatment (vermicompost) is a nutrient-rich organic fertilizer and has revealed a significant role in plant growth. Vermicompost contains many nutrients that are needed for plants, such as nitrogen, potassium, phosphorus, and calcium (Singh et al., 2011). However, the limitation of this treatment is its slow process, and some problems associated with vermicompost are the sensitivity of earthworms to changes in $\mathrm{pH}$, temperature, and water content. Therefore, these parameters must be controlled during the process (Rupani et al., 2010).

\section{Membrane filtration technology}

Membrane filtration is the physical treatment characterized by the ability to separate molecules of different 
sizes and characteristics. Membranes with different permeability are used to filter out the suspended particles in the effluent (Goswami et al., 2018). In direct membrane filtration systems, membrane separation plays a role in effectively rejecting organic matter of wastewater, leading to superior seepage quality with a high-water recovery ratio. The process does not involve any additional activated sludge processes, which leads to a reduction in the consumption of energy. Furthermore, the filtering process enriches waste organics and nutrients, resulting in renewable energy or fertilizer (Abdurahman et al., 2017; Ahmad et al., 2003).

Some advantages of membrane filtration for POME treatment are as follows: it can filter suspended solids at high efficiency, the biogas released during anaerobic decomposition can be recovered for electricity generation, the installation cost is lower, so is the energy cost (Abdurahman et al., 2017). Membrane filtration could prevent eutrophication by removing the nutrients from POME such as nitrogen and phosphorus (Aziz et al., 2020). However, the membrane filtration technology for POME has many limitations. Firstly, the high flow rates used in cross-flow feed can destruct shear sensitive materials. Secondly, the process is prone to membrane fouling effects, which leads to a reduction in permeate flux. Finally, if the membrane manufacturing process is not precisely controlled, membranes with a wide pore size distribution can resulting poor separation performance (Lee et al., 2019).

\section{Photocatalysis treatment}

Photocatalysis is the type of physical treatment that accelerates the photoreaction in the presence of catalysts. Photocatalysis is an eco-friendly, effective, and economical technology to treat various wastewaters and it has received a lot of concern from scientists. The photocatalytic reaction shows high efficiency in the degradation of pollutants and the disinfection of pathogenic microorganisms in wastewater. Various materials have been tested in photocatalysis and as a conclusion, the materials are classified into four types: titanium dioxide, sulfides, polymeric carbon nitrite, and bismuth-based photocatalysts. Titanium dioxide is chosen as a popular catalyst to decompose the organic compounds due to its low toxicity, low cost, suitability in the conduction band, and the valence band position for degradation of pollutants. During the photocatalytic process, there must be two reactions taking place simultaneously: the oxidation of the photogenerated holes and the reduction of the photogenerated electrons. The photocatalyst itself should not undergo changes, and therefore proper synchronization of the two processes needs to be carried out (Alhaji et al., 2016; Alhaji et al., 2018). Ng et al. (2019b) and Tang et al. (2021) suggest that pre-treatment such as filtration should be conducted before photocatalysis to avoid the fibers from shielding the UV penetration through the effluent.

The advantage of photocatalysis is that the organic compounds are decomposed at an aqueous state and some heavy metals are removed during the effluent treatment. The titanium dioxide can withstand biological and chemical corrosion so the replacement of the titanium dioxide is not frequent ( $\mathrm{Ng}$ et al., 2019b). The cost of removing sludge can be saved as there is no sludge produced during the photocatalysis (Alhaji et al., 2016). The disadvantage of photocatalysis is that the release of titanium dioxide to the environment increases the ecological footprint (Lee et al., 2019). The titanium dioxide is needed to be separated from the treated effluent after the treatment and the efficiency is inversely proportional to the cloudiness of the effluent (Alhaji et al., 2018).

\section{MBBR}

MBBR is an advanced technology that combines biofilm and activated carbon processes to increase the efficiency of wastewater treatment. The technology was invented by Hallvard Odegaard in 1989 and developed in Scandinavia in the early 1990s by Kaldness Miljiteknology in cooperation with a Norwegian research institute, Selskapet for Industriell og Teknisk Forskning. MBRRs have become popular in Europe and has been installed in many industrial wastewater treatments such as cheese factory, pulp and paper industry, and poultry processing. The principle of the MBBR is an initiation of the process with a high concentration of microbial biomass by improving suspended and attached growth systems. The MBBR comprises several components such as biofilm, flow configuration, aeration system, and media. The biofilm is a slim layer of microorganisms in organic and inorganic materials that stick to wet surfaces. The important components for biofilm growth are the microorganism, its substrate, and water. Water is very crucial in the development of biofilm growth because it determines bacterial life and nutrient 
availability. Water is also needed by bacteria to maintain their osmotic pressure (Bakar et al., 2018). In the MBBR system, the microbe's breakdown of the organic compounds is suspended in the effluent and reduces BOD and COD levels significantly (Leyva-Díaz et al., 2020).

The advantage of the MBBR is less space required for the reactor to set up, so there is an extra space for palm oil mill development (Bakar et al., 2018). Backwashing is not required for this MBBR as the dead space which causes clogging and channeling is avoided; the MBBR can process a high density of biomass. The nitrates generated from nitrification are used as fertilizers in an oil palm farm to reduce the expenses on fertilizers on the farm (Leyva-Díaz et al., 2020). The disadvantage of the MBBR is the extra cost needed for the aeration in the MBBR as oxygen is required to allow the fluidization in the reactor. There is a high construction cost of the MBBR and carriers in the reactors, which may not be affordable for all palm oil mill owners. The stagnant zones in the MBBR might reduce the complete mixing in the MBBR, which reduces the efficiency of effluent treatment (Leyva-Díaz et al., 2020).

\section{ZLD treatment}

ZLD treatment is a water treatment process in which all the wastewater is fully utilized and recovered. The ZLD treatment is the combination of several treatment methods to treat POME such as ultrafiltration, reverse osmosis, crystallization, and fractional electrode-ionization. When the ZLD system is implemented, no water is discharged from a closed water cycle; instead, the water is reused after suitable treatment. This eliminates the risk of water contamination through wastewater disposal and also maximizes the efficiency of water use. Currently, ZLD technology has received increasing interest due to severe water shortages and contamination of aquatic environments across the globe. Three types of ZLD commonly implemented in the wastewater treatment plant are thermal ZLD system, RO-incorporated thermal ZLD systems, and emerging membrane-based ZLD systems. The key process involved in the thermal ZLD system includes wastewater pre-treatment, brine concentrator, brine crystallizer, followed by evaporation pond, and solids recovery. In the RO-incorporated thermal ZLD systems, the RO is implemented between pre-treatment and the brine concentrator while membrane distillation (MD), forward osmosis (FO), and electrodialysis (ED) are installed after the pre-treatment (Loh et al., 2013; Tabassum et al., 2015).

The advantage of ZLD is that the expenses of a palm oil mill and a palm oil farm can be reduced since fertilizers and electricity are generated during sludge and biogas recovery. Due to the application of pre-treatment, the maintenance cost is reduced as the pre-treated effluent causes less damage to membranes and reactors (Tabassum et al., 2015), so membranes are replaced less frequently. This treatment ensures that all products during each stage are fully utilized, which can reduce the wastes and convert the wastes into resources. The final product of treatment is used to irrigate oil palm trees as a fertilizer. The disadvantage of zero-discharge treatment is the high capital cost required to build the whole treatment system, so less palm oil mill owners apply the treatment method (Lee et al., 2019).

\section{Conclusions}

Indonesia and Malaysia are the leading exporters of palm oil worldwide with $84 \%$ of worldwide production. In Malaysia, most of the oil palm plantations are owned by private estates conglomerates (61\%), independent smallholders (16\%), FELDA (13\%), state agencies (6 $\%)$, FELCRA (3 \%), and RISDA (1\%). Although the commercial plantation of oil palm trees can boost the country's economy, environmental concerns associated with oil palm plantation must be addressed in order to avoid environmental damage. The palm oil mill effluent, which comprises a high biological oxygen requirement, chemical oxygen, and other chemicals, must be thoroughly treated prior to discharge into the environment. Different treatment methods with advantages and disadvantages of each method are discussed. For the different scales of a palm oil mill, different effluent treatment methods are applied to fit the palm oil mill's financial capability. Every method reduces environmental pollutants in the palm oil effluent so that the final product is safe for the environment. It is recommended to apply zero discharge treatment as it can fully utilize the waste palm oil mill effluent as a resource. With the development of science and technology, the zero-discharge treatment can be improved and made affordable to all palm oil mills, which can reduce wastes generation. 


\section{Acknowledgements}

The authors thank Indonesia Institute of Sciences and Curtin University Malaysia for facilitating this work.
Collaboration from Institut Teknologi Sepuluh Nopember and Syiah Kuala University Indonesia is highly appreciated.

\section{References}

Aziz, M.M.A., Kassim, K.A., ElSergany. V.M., Anuar, S., Jorat, M.E., Yaacob, H., Ahsan, A., Imteaz, M.A., and Arifuzzaman. (2020). Recent advances on palm oil mill effluent (POME) pretreatment and anaerobic reactor for sustainable biogas production. Renew. Sust. Energy Rev., 119, 109603. https://doi. org/10.1016/j.rser.2019.109603

Abbas, Z., Arooj, F., Ali, S., Zaheer, I.E., Rizwan, M., and Riaz, M.A. (2019). Phytoremediation of landfill leachate waste contaminants through floating bed technique using water hyacinth and water lettuce. Int. J. Phytoremediation, 21, 1356-1367. https:// doi.org/10.1080/15226514.2019.1633259

Abdullah, I., Wan Mahmood, W.H., Fauadi, M.H.F.M., Rahman, M.N.A., and Ahmad, F. (2015). Sustainability in Malaysian palm oil: A review on manufacturing perspective. Polish J. Environ. Stud., 24, 1463-1475. https://doi.org/10.15244/pjoes/37888

Abdullah, N., and Sulaiman, F. (2013). The oil palm wastes in Malaysia, biomass now - sustainable growth and use, Martovic MD, IntechOpen. https://www.intechopen.com/books/ biomass-now-sustainable-growth-and-use/the-oil-palmwastes-in-malaysia https://doi.org/10.5772/55302

Abdurahman, N.H., Azhari, H.N., and Said, N. (2017). An integrated ultrasonic membrane an aerobic system (IUMAS) for palm oil mill effluent (POME) treatment. Energy Procedia 138,1017-1022. https://doi.org/10.1016/j.egypro.2017.10.120

Abdurahman, N.H., Rosli, Y.M., and Azhari, N.H. (2013). The performance evaluation of anaerobic methods for palm oil mill effluent (POME) treatment: A review. Int Perspectives Wat Quality Manag Pollut Cont, Queen NWT, IntechOpen Chap 4:87-106. https:// www.intechopen.com/books/international-perspectives-on-water-quality-management-and-pollutant-control/the-performance-evaluation-of-anaerobic-methods-for-palm-oil-mill-effluent-pome-treatment-a-review https://doi.org/10.5772/54331

Ahmad, A.L., Bhatia, S., Ibrahim, N., and Sumathi, S. (2005a). Adsorption of residual oil from palm oil mill effluent using rubber powder. Brazilian J. Chem. Eng. 22(3), 371-379. https://doi. org/10.1590/S0104-66322005000300006

Ahmad, A.L., Ismail, S., and Bhatia, S. (2003). Water recycling from palm oil mill effluent (POME) using membrane technology. Desalination 157, 87-95. https://doi.org/10.1016/S00119164(03)00387-4
Ahmad, A.L., Ismail, S., and Bhatia, S. (2005b). Optimization of coagulation-flocculation process for palm oil mill effluent using response surface methodology. Environ. Sci. Technol., 39(8), 2828-2834. https://doi.org/10.1021/es0498080

Akhbari, A., Kutty, P.K., Chuen, O.C., and Ibrahim, S. 2019. A study of palm oil mill processing and environmental assessment of palm oil mill effluent treatment. Environ. Eng. Res., 25(2), 212-221. https://doi.org/10.4491/eer.2018.452

Alhaji, M.H., Sanaullah, K., Lim, S.F., Khan, A., Hipolito, C.N., Abdullah, M.O., Bhawani, S.A., and Jamil, T. (2016). Photocatalytic treatment technology for palm oil mill effluent (POME) - A review. Process Saf. Environ. Prot., 102, 673-686. https://doi. org/10.1016/j.psep.2016.05.020

Alhaji, M.H., Sanaullah, K., Salleh, S.F., Baini, R., Lim, S.F., Rigit, A.R.H., Said, K.A.M., and Khan, A. (2018). Photooxidation of pre-treated palm oil mill Effluent using cylindrical column immobilized photoreactor. Process Saf. Environ. Prot., 50,180189. https://doi.org/10.1016/j.psep.2018.04.012

Awalludin M.F., Sulaiman O., Hashim R., Nadhari, W.N.A.W. 2015. An overview of the oil palm industry in Malaysia and its waste utilization through thermochemical conversion, specifically via liquefaction. Renew. Sust. Energy Rev., 50, 1469-1484. https://doi.org/10.1016/j.rser.2015.05.085 https://doi.org/10.1016/j.rser.2015.05.085

Bakar S.N.H.A., Hasan H.A., Mohammad A.W., Abdullah S.R.S., Haan T.Y., Ngteni R, and Yusof K.M.M. (2018) A review of moving-bed biofilm reactor technology for palm oil mill effluent treatment. J Cleaner Prod 171, 1532-1545. https://doi. org/10.1016/j.jclepro.2017.10.100

Borja, R., and Banks, C.J. (1994) Treatment of palm oil mill effluent by upflow anaerobic filtration. J. Chem. Tech. Biotechnol. 61, 103-109. https://doi.org/10.1002/jctb.280610204

Chan, Y.J., Chong, M.F., and Law, C.L. (2012). An integrated anaerobic-aerobic bioreactor (IAAB) for the treatment of palm oil mill effluent (POME): Start-up and steady state performance. Process Biochem., 47(3),485-495. https://doi.org/10.1016/j. procbio.2011.12.005

Chan, Y.J., Chong, M.F., Law, C.L., and Hassell, D.G. (2009). A review on anaerobic-aerobic treatment of industrial and mu- 
nicipal wastewater. Chem. Eng. J., 155(1-2),1-18. https://doi. org/10.1016/j.cej.2009.06.041

Cheng, Y.W., Ng, K.H., Lam, S.S., Lim, J.W., Wongsakulphasatch, S., Witoon, T., and Cheng, C.K. (2019). Syngas from catalytic steam reforming of palm oil mill effluent: An optimization study. Int. J. Hydrogen Energy, 44(18), 9220-9236. https://doi. org/10.1016/j.ijhydene.2019.02.061

Chin, Y.C., Jing, C.Y., Kheang, L.S., Vimala, S.C., Chin, S.A., Fong, C.M., Lye, C.C., and Keong, L.L. (2020). Comparison of different industrial scale palm oil mill effluent anaerobic systems in degradation of organic contaminants and kinetic performance. J. Cleaner Prod., 262, 121361. https://doi.org/10.1016/j.jclepro.2020.121361

da-Silva, C.J., Canatto, R.A., Cardoso, A.A., Ribeiro, C., and Oliveira, J.A. (2017). Arsenic-hyperaccumulation and antioxidant system in the aquatic macrophyte Spirodela intermedia W. Koch (Lemnaceae). Theor. and Exp. Plant Physiol., 29, 203-213. https://doi.org/10.1007/s40626-017-0096-8

Daud, M.K., Ali, S., Abbas, Z., Zaheer, I.E., Riaz, M.A., Malik, A., Hussain, A., Rizwan, M., Zia-ur-Rehman, M., and Zhu, S.J. (2018). Potential of Duckweed Lemna minor for the Phytoremediation of Landfill Leachate. J. Chem., 2018, 3951540. https://doi.org/10.1155/2018/3951540

Donald, P.F. (2004). Biodiversity Impacts of Some Agricultural Commodity Production Systems. Conservat. Biol., 18, 17-38. https://www.jstor.org/stable/3589112 https://doi.org/10.1111/ j.1523-1739.2004.01803.x

Eze, I.C., Schaffner, E., Fischer, E., Schikowski, T., Adam, M., Imboden, M., Tsai, M., Carballo, D., von Eckardstein, A., Künzli, N., Schindler, C., and Probst-Hensch, N. (2014). Long-term air pollution exposure and diabetes in a population-based Swiss cohort. Environ. Inter., 70, 95-105. https://doi.org/10.1016/j. envint.2014.05.014

Goswami, L., Kumar, R.V., Borah, S.N., Manikandan, N.A., Pakshirajan, K., and Pugazhenthi, G. (2018). Membrane bioreactor and integrated membrane bioreactor systems for micropollutant removal from wastewater: A review. J. Wat. Process Eng., 26, 314-328. https://doi.org/10.1016/j.jwpe.2018.10.024

Gunathilakae, N., Yapa, N., and Hettiarachchi, R. (2018). Effect of arbuscular mycorrhizal fungi on the cadmium phytoremediation potential of Eichhornia crassipes (Mart.) Solms. Groundwater Sust. Dev., 7, 477-482. https://doi.org/10.1016/j.gsd.2018.03.008 Hadibarata, T., Khudhair, A.B., Kristanti, R.A., and Kamyab, H. 2017. Biodegradation of pyrene by Candida sp. S1 under high salinity conditions. Biopro Biosys. Eng., 40(9), 1411-1418. https://doi.org/10.1007/s00449-017-1798-7

Hariz, H.B., Takriff, M.S., Yasin, N.H.M., Ba-Abbad, M.M., and Hakimi, N.I.N.M. (2019). Potential of the microalgae-based integrated wastewater treatment and $\mathrm{CO} 2$ fixation system to treat Palm Oil Mill Effluent (POME) by indigenous microalgae; Scenedesmus sp. and Chlorella sp. J. Wat. Process Eng., 32, 100907. https://doi.org/10.1016/j.jwpe.2019.100907

Hashiguchi, Y., Zakaria, M.R., Maeda, T., Yusoff, M.Z.M., Hassan, M.A., and Shirai, Y. (2020). Toxicity identification and evaluation of palm oil mill effluent and its effects on the planktonic crustacean Daphnia magna. Sci. Tot. Env., 710, 136277. https://doi. org/10.1016/j.scitotenv.2019.136277

Harsono, S., Grundmann, P., and Soebroto, S. (2014). Anaerobic treatment of palm oil mill effluents: Potential contribution to net energy yield and reduction of greenhouse gas emission from biodiesel production, J. Cleaner Prod., 64, 619-627. https://doi. org/10.1016/j.jclepro.2013.07.056

Hii, H. T. (2021). Adsorption Isotherm and Kinetic Models for Removal of Methyl Orange And Remazol Brilliant Blue R By Coconut Shell Activated Carbon. Tropical Aquatic Soil Pollut., 1(1), 1-10. https://doi.org/10.53623/tasp.v1i1.4

Huzir, N.M., Aziz, M.M.A., Ismail, S.B., Mahmood, N.A.N., Umor, N.A., and Muhammad, S.A.F.S. (2019). Optimization of coagulation-flocculation process for the palm oil mill effluent treatment by using rice husk ash. Ind. Crops Prod., 139,111482. https:// doi.org/10.1016/j.indcrop.2019.111482

Iha, D.S., and Bianchini, I. (2015). Phytoremediation of Cd, Ni, $\mathrm{Pb}$ and $\mathrm{Zn}$ by Salvinia minima. Int. J. Phytoremediation 17, 929935. https://doi.org/10.1080/15226514.2014.1003793

Irvan. (2018). Processing of palm oil mill wastes based on zero waste technology. IOP Conference Serie: Mat. Sci. Eng., 309, 012136. https://doi.org/10.1088/1757-899X/309/1/012136

Izah, S.C., Angaye, T.C.N., and Ohimain, E.I. (2016). Environmental Impacts of Oil Palm Processing in Nigeria. Biotechnol. Res. 2(3), 132-141. https://www.researchgate.net/publication/311709429 Jayakumar, S., Yusoff, M., Rahim, M.H.A., Maniam, G.P., and Govindan, N. (2017). The prospect of microalgal biodiesel using agro-industrial and industrial wastes in Malaysia. Renew. Sust. Energy Rev., 72, 33-47. https://doi.org/10.1016/j.rser.2017.01.002

Johari, A., Nyakuma, B., Nor, S.H.M., Mat, R., Hashim, H., Ahmad, A., Zakaria, Z., Abdullah, T.A.T. 2015 The challenges and prospects of palm-oil based biodiesel in Malaysia. Energy 81, 255-261. https://doi.org/10.1016/j.energy.2014.12.037

Kadir, A.A., Abdullah, S.R.S., Othman, B.A., Hasan, H.A., Othman, A.R., Imron, M.F., Ismail, N.I., and Kurniawan, S.B. (2020). Dual function of Lemna minor and Azolla pinnata as phytoremediator for Palm Oil Mill Effluent and as feedstock. Chemosphere 259, 127468. https://doi.org/10.1016/j.chemosphere.2020.127468

Kamyab, H., Chelliapan, S., Din, M.F.M., Rezania, S., Khademi, T., and Kumar, A. (2018). Palm Oil Mill Effluent as an Environmental Pollutant, Palm Oil, Viduranga Waisundara, Inte- 
chOpen, 13-30. https://www.intechopen.com/books/palm-oil/ palm-oil-mill-effluent-as-an-environmental-pollutant https:// doi.org/10.5772/intechopen.75811

Kelishadi, R., and Poursafa, P. (2010). Air pollution and non-respiratory health hazards for children. Arch. Med. Sci., 6, 483495. https://doi.org/10.5114/aoms.2010.14458

Khadaroo, S.N.B.A., Poh, P.E., Gouwanda, D., and Grassia, P. (2019). Applicability of various pretreatment techniques to enhance the anaerobic digestion of Palm oil Mill effluent (POME): A review. J. Environ. Chem. Eng., 7(5), 103310. https://doi. org/10.1016/j.jece.2019.103310

Kristanti, R. A., Liong, R. M. Y., and Hadibarata, T. (2021). Soil Remediation Applications of Nanotechnology. Tropical Aquatic Soil Pollut., 1(1), 35-45. https://doi.org/10.53623/tasp.v1i1.12

Lai, H. J. (2021). Adsorption of Remazol Brilliant Violet 5R (RBV$5 R$ ) and Remazol Brilliant Blue R (RBBR) from Aqueous Solution by Using Agriculture Waste. Tropical Aquatic Soil Pollut., 1(1), 11-23. https://doi.org/10.53623/tasp.v1i1.10

Lee, Z.S., Chin, S.Y., Lim, J.W., Witoon, T., and Cheng, C.K. (2019). Treatment technologies of palm oil mill effluent (POME) and olive mill wastewater (OMW): A brief review. Environ. Technol. Inn., 15,100377. https://doi.org/10.1016/j.eti.2019.100377

Lek, B.L.C., Peter, A.P., Chong K.H.Q., Ragu, P., Sethu, V., Selvarajoo, A., and Arumugasamy, S.K. (2018). Treatment of palm oil mill effluent (POME) using chickpea (Cicer arietinum) as a natural coagulant and flocculant: Evaluation, process optimization and characterization of chickpea powder. J. Environ. Chem. Eng., 6(5), 6243-6255. https://doi.org/10.1016/j. jece.2018.09.038

Leyva-Díaz, J.C., Monteoliva-García, A., Martín-Pascual, J., Munio, M.M., García-Mesa. J.J., and Poyatos, J.M. (2020). Moving bed biofilm reactor as an alternative wastewater treatment process for nutrient removal and recovery in the circular economy model. Bioresource Technol. 299, 122631. https://doi. org/10.1016/j.biortech.2019.122631

Lim, S.L., and Wu, T.Y. 2015. Determination of maturity in the vermicompost produced from palm oil mill effluent using spectroscopy, structural characterization and thermogravimetric analysis. Eco. Eng. 84, 515-519. https://doi.org/10.1016/j.ecoleng.2015.09.050

Loh, S.K., Lai, M.E., Ngatiman, M., Lim, W.S., Choo, Y.M, Zhang, Z.J.M., and Salimon, J. (2013). Zero discharge treatment technology of palm oil mill effluent. J. Oil Palm Res., 25(3), 273-281. https://www.researchgate.net/publication/260917494

Mohd-Nor, D., Ramli, N., Sharuddin, S.S., Hassan, M.A., Mustapha, N.A., Ariffin, H., Sakai, K., Tashiro, Y., Shirai, Y., and Maeda, T. (2019). Dynamics of Microbial Populations Responsible for Biodegradation during the Full-Scale Treatment of Palm
Oil Mill Effluent. Microbes Environ., 34, 121-128. https://doi. org/10.1264/jsme2.ME18104

Malaysian Palm Oil Board (MPOB). 2016. Overview of the Malaysian Oil Palm Industry 2015. http://palmoilis.mpob.gov.my/V4/ wpcontent/uploads/2020/03/Overview_of_Industry_2015.pdf

Malaysian Palm Oil Board (MPOB). 2018. Overview of the Malaysian Oil Palm Industry 2017. http://palmoilis.mpob.gov.my/ V4/overview-of-industry-2017.pdf

Malaysian Palm Oil Board (MPOB)MPOB. 2019. Overview of the Malaysian Oil Palm Industry 2018.http://palmoilis.mpob. gov.my/V4/wpcontent/uploads/2020/03/Overview_of_Industry_2018.pdf

Monir, M.U., Abd Aziz A., Kristanti, R.A., and Yousuf, A. 2018. Gasification of lignocellulosic biomass to produce syngas in a 50-kW downdraft reactor. Biomass and Bioenergy, 119, 335345. https://doi.org/10.1016/j.biombioe.2018.10.006

Nasrullah, M., Singh, L., Krishnan, S., Sakinah, M., Mahapatra, D.M., and Zularisam, A.W. (2020). Electrocoagulation treatment of raw palm oil mill effluent: Effect of operating parameters on floc growth and structure. J. Wat. Process Eng. 33, 101114. https://doi.org/10.1016/j.jwpe.2019.101114

Ng, K.H., Cheng, Y.W., Lee, Z.S., and Cheng, C.K. (2019a). A study into syngas production from catalytic steam reforming of palm oil mill effluent (POME): A new treatment approach. Int. J. Hydrogen Energy, 44(37),20900-20913. https://doi.org/10.1016/j. ijhydene.2018.04.232

Ng, K.H., Yuan, L.S., Cheng, C.K., Chen, K., and Fang, C. (2019b). TiO2 and ZnO photocatalytic treatment of palm oil mill effluent (POME) and feasibility of renewable energy generation: A short review. J. Cleaner Prod., 233(8), 209-225. https://doi. org/10.1016/j.jclepro.2019.06.044

Ng, Y.S., and Chan, D.J.C. (2017). Wastewater phytoremediation by Salvinia molesta. J. Wat. Process Eng., 15, 107-115. https:// doi.org/10.1016/j.jwpe.2016.08.006

Ngieng, H. Y., Hadibarata, T., and Rubiyatno. (2021). Utilization Of Construction And Demolition Waster And Environmental Management Practice In South East Asian Countries. Tropical Aquatic Soil Pollut., 1(1), 46-61. https://doi.org/10.53623/tasp. v1i1.13

Ohimain, E.I., and Chibuezelzah, S. (2017). A review of biogas production from palm oil mill effluents using different configurations of bioreactors. Renew. Sust. Energy Rev., 70, 242-253. https://doi.org/10.1016/j.rser.2016.11.221

Okwute, L., Emmanuel, S., and Anyanwu, P. (2015). Biodegradation of Palm Oil Mill Effluent (POME) and Lipase Activity by Pseudomonas aeruginosa, Bacillus subtilis and Candida albicans. British Microbiol Res. J., 9, 1-10. https://doi.org/10.9734/ BMRJ/2015/18601 
Omran, A., and Schwarz-Herion, O. (2020) Deforestation in Malaysia: The Current Practice and the Way Forward. In Omran, A., Schwarz-Herion, O. (eds), Sustaining our Environment for Better Future, Springer, Singapore https://doi.org/10.1007/978981-13-7158-5

Rupani, P.F., Singh, R.P., Ibrahim, M.H., and Esa, N. (2010) Review of Current Palm Oil Mill Effluent (POME). World Appl. Sci. J., 10(1),1190-1201. https://www.researchgate.net/publication/213965918

Sia, Y.Y., Tan, I.A.W., and Abdullah, M.O. (2017). Adsorption of colour, TSS and COD from palm oil mill effluent (POME) using acid-washed coconut shell activated carbon: Kinetic and mechanism studies. MATEC Web. Conf., 87, 03010. https://doi. org/10.1051/matecconf/20178703010

Singh, R.P., Embrandiri, A., Ibrahim, M.H., and Esa, N. (2011). Management of biomass residues generated from palm oil mill: Vermicomposting a sustainable option. Resour. Conserv. Recycl., 55(4), 423-434. https://doi.org/10.1016/j.resconrec.2010.11.005

Sumathi, S., Chai, S.P., and Mohamed, A.R. (2008). Utilization of oil palm as a source of renewable energy in Malaysia. Renew. Sust. Energy Rev., 12, 2404-2421. https://doi.org/10.1016/j. rser.2007.06.006

Syahza, A. (2019). The potential of environmental impact as a result of the development of palm oil plantation. Manage. Environ. Quality Int. J., 30, 1072-1094. https://doi.org/10.1108/ MEQ-11-2018-0190

Tabassum, S., Zhang, Y., and Zhang, Z. (2015). An integrated method for palm oil mill effluent (POME) treatment for achieving zero liquid discharge - A pilot study. J. Cleaner Prod., 95, 148-155. https://doi.org/10.1016/j.jclepro.2015.02.056

Tan, Y.D., and Lim, J.S. (2019). Feasibility of palm oil mill effluent elimination towards sustainable Malaysian palm oil in- dustry. Renew. Sust. Energy Rev., 111,507-522. https://doi. org/10.1016/j.rser.2019.05.043

Tang, K. H. D. (2021). Interactions of Microplastics with Persistent Organic Pollutants and the Ecotoxicological Effects: A Review. Tropical Aquatic Soil Pollut., 1(1), 24-34. https://doi. org/10.53623/tasp.v1i1.11

Vijay, V., Pimm, S.L., Jenkins, C.N., and Smith, S.J. (2016). The Impacts of Oil Palm on Recent Deforestation and Biodiversity Loss. PLOS ONE 11: e0159668. https://doi.org/10.1371/journal.pone.0159668

Von Schenck, W. (2020). Union Zur Forderung Von Oel-Und Proteinpflanzen E.V (UFOP) (2020) UFOP report on global market supply 2019/2020. Agricultural Market Information Company (AMII). https://www.ufop.de/files/7215/7953/0161/ WEB_UFOP_Global_Supply_Report_A5_EN_19_20.pdf

Wahab, A.G. (2019). Malaysia: Biofuels Annual. United States Department of Agriculture.

Wu, T.Y., Mohammad, A.W., Jahim, J.M., and Anuar, N. (2010). Pollution control technologies for the treatment of palm oil mill effluent (POME) through end-of-pipe processes. J. Environ. Manage. 91(7),1467-1490. https://doi.org/10.1016/j.jenvman.2010.02.008

Yap, C.C., Chan, Y.J., Loh, S.K., Supramaniam, C.V., Soh, A.C., Chong, M.F., Chew, C., and Lim, L.K. (2020). Comparison of different industrial scale palm oil mill effluent anaerobic systems in degradation of organic contaminants and kinetic performance. J Cleaner Prod 262, 121361. https://doi.org/10.1016/j. jclepro.2020.121361

Zhang, P., Chen, X., Leng, Y., Dong, Y., Jiang, P., and Fan, M. (2020). Biodiesel production from palm oil and methanol via zeolite derived catalyst as a phase boundary catalyst: An optimization study by using response surface methodology. Fuel 272, 117680. https://doi.org/10.1016/j.fuel.2020.117680 